\title{
Privilege, shame and new choices towards reconciliation. An autobiographical approach
}

J C Müller

(University of Pretoria)

\section{ABSTRACT \\ Privilege, shame and new choices towards reconciliation. An autobiographical approach}

A narrative and autobiographical approach is taken in this article in order to explore and explain reconciliation. In the process the concepts of privilege, shame and new choices, within a specific story, are taken as the guiding beacons on the road to reconciliation in the South African situation.

There are all kinds of stories. Some are born with the telling: their substance is language, and before someone puts them into words they are but a hint of an emotion, a caprice of mind, an image, or an intangible recollection. Others are manifest whole, like an apple, and can be repeated infinitely without risk of altering their meaning. Some are taken from reality and processed through inspiration, while others rise up from an instant of inspiration and become real after being told. And there are secret stories that remain hidden in the shadows of the mind; they become covered with excrescences and parasites, and with time are transformed into the matter of nightmares. To exorcise the demons of memory, it is sometimes necessary to tell them as a story (Allende 1988:158).

I share my own story in this article not because it is extraordinary or special. To the contrary! I write it because it is so very ordinary and shared by many Afrikaans speaking people of my age. And I am glad for the opportunity because I am convinced that there is an urgent need in our society to exorcise "the demons of memory". The way to do that is to remember and to tell the stories. Therefore, the assumption with which I operate in this article is that reconciliation is a narrative construct and can only be achieved on a narrative basis.

I grew up as a farm boy and the only son of Christian parents. 
My story of inter-cultural and racial relations was determined by at least the following forces:

1. Good loving relations;

2. Superiority;

3. Marginalisation;

4. Strong motivation to overcome backlogs.

I will illustrate these by telling two personal stories and a quote from the book of Antjie Krog, A Change of Tongue (2003).

\section{STORY 1}

We lived on a farm on the eastern highveld. I was the middle child of three, the only boy. One of my earliest memories is about a birthdayexperience. I think it was my third birthday. I was ecstatic when I received my birthday present: a few plastic-cars, packed in a row in a long box.

My first reaction was to show this wonderful birthday present to my best friend. Daniel was a black boy who lived and worked with his parents on our farm. Everyday we played together, unaware of the class-distinction between us. I found him in the outbuilding and we sat down to look at the cars. He was slightly older than I was and he sat on a small bench, whilst I sat on the floor in front of him. One by one the cars were taken out and we looked at it with wonder. Eventually Daniel took the two nicest cars and nonchalantly pushed them backwards underneath his bench, almost as if to say that he now considered these two to be his. I do not recall the precise details of what happened next, but there must have been a big row and I got my cars back. After all, although younger than Daniel, I was the boss' son and there was no way that Daniel could take my birthday present.

\section{STORY 2}

The rural area of Nigel, where I grew up, was a stronghold of the Nationalist Party. It was the electoral ward of John Vorster, who later became Prime Minister. But my parents at that time were "Sappe". They supported the United Party (legacy of Smuts), which grew out of the South African Party (SAP). We, the "Sappe", were by far in the minority in that farming community. 
I remember one day standing on the playground of the primary school. I must have been in grade 3 or 4 . A group of boys were sitting nearby and I became aware of them pointing at me and making jokes about me being a "Sap". For a young boy looking for the approval of his peers, this was a painful experience of marginalization.

This little memory serves to illustrate the strong position of the dominant party during the fifties and how socially ostracised you felt when you were not part of that.

\section{STORY FROM ANTJIE KROG'S BOOK}

Antjie Krog (2003:68-69) asked her mother about the situation of the Afrikaner after they came into power in 1948:

Were you criticized when you came to power in 1948?

'What are you talking about! "Criticized" is much too mild a word we were ridiculed, derided, disdained, reviled. It was simply a continuation from the Anglo-Boer War, when we were described as hairy barbarians, takhare and backvelders. Everything we were was worthy of ridicule, our language, our political leaders, our intellectuals, our newspapers, our universities, our music, our literature or what we dared to think of as one, even our bodies - fat, coarse women and bearded, spiting men. Nothing we had was worthy of respect. We were simply lazier, more stupid, more corrupt than any English person.' My mother closes the Marmite jar and puts a dolly over the jam. 'It is hard to describe now, but you felt that you were thought of as a one-dimensional being, as if you had no ancestry, no culture that would be able to give you real depth. If you did something worthwhile, it was purely by chance, and tomorrow it would be exposed as stolen or mistaken'.

'But how did you deal then with criticism in the fifties and sixties?'

'We minimized contact with it. We stopped reading their newspapers - why should we expose ourselves to daily ridicule? We didn't go to their universities, we didn't listen to their radio programmes. If we had a need of something, we created it ourselves, our own films, our own books, our own history, our own Afrikaner business and millionaires. We appointed our own people to build up 
our confidence. We looked after our own poor. If it wasn't for that, we'd still be skulking around feeling inadequate'.

I hope that with these stories I have captured something of the paradoxical nature of the South African story. A variety of motives have all worked together in forming the Afrikaner identity that informed my upbringing.

I wasn't brought up as a racist, but on the other hand, we as a family were part and parcel of the racist discourse in the South African society of the time. The South African society was a typical example of a system organized on the basis of privilege. Systems organized around privilege have three key characteristics. "They are dominated by privilege groups, identified with privilege groups, and centered on privilege groups" (Johnson 2001:96). Therefore, although I have been brought up with the morality of love and respect for others, also for black people, we were also part and parcel of a system of domination. I was brought up, like many of my peers, to accept this discourse of privilege as something normal and unquestioned.

It was kind of natural for me as a young church minister to associate more with my own people (white Afrikaner), than with members of the black community, or even the non-Afrikaans community. I became a member of the Afrikaner Broederbond, and I remember well how, in many conversations, I vigorously defended the cause of the Afrikaner and the moral justifiability of apartheid. After I was appointed as pastor to students in 1978, at a Dutch Reformed congregation (Universiteitsoord) in Pretoria, I gradually changed. Obviously, in working with students, I was under the influence of a young generation's way of thinking. Slowly I began to disassociate myself from conservative and ideological Afrikaner ideas. I remember accompanying a group of students to Soweto during one winter holiday, and the wretched living conditions of the people there made a deep impact on me.

Today, when I think back, I am ashamed that 1 did not come to other insights sooner than 1 did. In 1997, when 1, along with a group of theologians, co-signed an open letter, which we submitted to the Truth and Reconciliation Commission, it was for me a personal confession of reluctance to accept change and of blindness to the oppressing realities 
of others. I had wasted valuable years as a pastor to students and did not do enough to promote a social-ethical conscience under young Afrikaners.

Soon after I had been appointed as a lecturer in the Dutch Reformed Faculty of Theology at the University of Pretoria in 1990, I had opportunity to attend a consultation in Nairobi, Kenya. We entered into dialogue with a delegation from the All Africa Council of Churches. I was greatly impressed by their intellectualism, genuine spirituality, and general attitude towards us. This happened before Mandela was freed. We were still not able to obtain visas for Kenya, and therefore special arrangements had to be made to allow us to enter the country.

During this visit to Kenya, I developed, for the first time, a deeply felt need to apologize for my involvement with the apartheid structures. I had already realized intellectually that we had made mistakes and that change had to happen. As a member of a group of Christians in a strange country, this became an emotional confession, which I expressed in a group meeting. I believe that this was a watershed moment in my attitude to - and view of - the situation in our country.

Afterwards, along with a number of my colleagues, I began to speak and preach differently. I wholeheartedly aligned myself with renewing thought, and when attending synods and meetings, I defended consequent non-racial and inclusive positions. I pleaded that the Dutch Reformed Church needed to make a full confession of its role in the apartheid structure, and that the Truth and Reconciliation Commission should serve as the forum for this. I used more than one of my columns (Church and Media) in the magazine of the Dutch Reformed Church (Die Kerkbode) to state this point. I was deeply disappointed when the General Synod Commission declined to take such a decision, and therefore, I decided to sign the open letter, referred to earlier. In this way I expressed my deeply felt need to confess my guilt for my part in the apartheid-ideology. During this period (1997), and after years of inactivity, I allowed my membership of the Afrikaner Broederbond to lapse. I could no longer made peace between being a minister of the church on the one hand and the association with the Afrikanerestablishment on the other. 
For too many years I was comfortable in the role of the one in charge, without a real critical reflection on that role. Naturally, the development of a political system such as apartheid is a complex issue. Many factors contributed to its development over many generations. The little black friend of my youth, Daniel and I were both products of social patterns, which had been established a long time ago. I was a part of the "haves" and he a part of the "have-nots" and it was neither of ours' fault that it was so. It was neither of us' fault that we were born into the roles of "boss" and "servant". However, I can never plead innocent to the charge that for too long I was insensitive to the position in which he and his group found themselves. I too easily accepted my privileged position for granted, and did not seek to empathize with them enough. Therefore I am ashamed, and once again, would like to confess my guilt for my part in an inequitable and unjust situation.

A few years ago, I was again confronted in a strange way with the re-authoring of my own story. I read an article in a newspaper and in that same time I had to accompany a group of Americans to the Voortrekker Monument.

\section{The renaming of a German military base ${ }^{1}$}

According to the New York Times, a German military base was recently renamed. The name of a famous army general, Günther Rüdel was replaced by that of a soldier in Hitler's army, Anton Schmid, who disobeyed orders, and by doing so saved the lives of hundreds of Jews. The Nazi's executed him during the war for his actions.

Indeed, a brave decision to make, and one with many consequences. As could be expected, not all in German society were in favour of this renaming. In his speech at the ceremony, the German minister of defense, Rudolf Scharping, defended the decision and said:

We are not free to choose our history, but we can choose the examples we take from that history.

I was moved when I read this story and it struck me again that reauthoring is a never-ending process. Sixty years after World War Two,

1 According to an article in the New York Times of May 9, 2000, A3. 
the German people are still struggling to interpret and re-author that part of their history.

Some people in South Africa feel that the past has been told efficiently and sufficiently enough. Perhaps the majority of white people were sceptical about the Truth and Reconciliation Commission, and they feel that they have heard enough of the shameful stories of apartheid. I don't agree. I feel it is necessary for us all to tell and re-tell our stories in order to "exorcise" the demons of racism for our society and our lives.

It is ironic that during this same time, Pope John Paul II did the opposite and made an apology of wrongs committed by Roman Catholics centuries ago (during a Mass of Pardon at St. Peter's Basilica). He implicitly talked about the Crusades, the Inquisition and the terrible inaction and silence in the face of the Holocaust. Of course, one can be skeptical of this confession. As Time ${ }^{2}$ pointed out: "It is awkward: How does infallibility own up to its fallibility and yet remain infallible? The Pope's solution: by being vague about the actual sins and by attributing them, in any case, to men and women who are Catholics and not to the Catholic Church itself”. Time also referred to the insufficient attention given to the wrongs done against women and homosexuals, but it gave credit to the Pope and said: "In the apology, the Pope does what a leader ought to do. He sets an example".

To my mind, the challenge of the church in South Africa is to create a dream for the future, but that cannot happen without the continuous telling of the past-story! The future must be created by, and through the telling of the past. There is no way to imagine a better future without the telling and the retelling of the past. The pastoral challenge is to facilitate a situation where re-authoring can take place. The stories of the past, although gruesome and shameful, must be told and told again until the new dream can take form.

Re-authoring is not a quick fix method. To re-author the story, in order for the two South African tales to become one, takes time. It is a lengthy process in which the church and church leaders should take the lead. At the moment, not even all the mainline churches in South Africa

2 Time, March 27 (2000:41). 
have joined in the confessing on the sins of apartheid. The Dutch Reformed Church has only recently come to a full confession of the sin of apartheid.

\section{ACCOMPANYING VISITORS TO THE VOORTREKKER MONUMENT}

On July 6, 2000, we, at the Faculty of Theology at the University of Pretoria, received a visit by faculty-members and students from the Columbia Theological Seminary in Atlanta, USA. Unexpectedly they asked me to accompany them to the Voortrekker Monument. The request came from my friend and colleague, Professor Erskine Clarke, whom I accompanied a few years ago to the same monument. I immediately agreed and we left for the monument. It turned out to be a painful experience for myself. It was the first time in about three years that I went to the shrine of Afrikaner nationalism.

While I was taking the group around and trying to explain the history of Blood River and the religious meaning that was given to the victory of white people over black tribes, I realized that I had changed. I experienced a mixture of feelings. On the one hand I still felt pride and cherished the proud history of the Afrikaner. On the other hand I couldn't escape thoughts of shame about what was done to others.

When driving home that evening I was in a state of shock. The situation caught me in a double bind. On the one hand, it was my history and I found myself telling the story of the Afrikaner people and the struggles of the past, in the same language with which I grew up. I had the feeling that I was expected to tell that story, and I tried my best to tell it as I was taught. On the other hand, I could no longer identify in the same way with that particular old story. I had the desire to reinterpret the story and at least also in include the perspective of indigenous black groups and their struggle against the white people invading their land. But to the group of foreigners I felt obliged to try and explain and even defend the past in the old language.

In the days after the visit to the Voortrekker Monument I thought once more of the story of the German military base and its renaming. I tried to give an account to myself of my own choices and my own interpretations of our history. I tried to think of names, people I would like to remember as examples on the basis of which I would like to 
build my own future. I felt like a traitor, but simultaneously had the urge to take the risk. Although there are many examples in the history of South Africa, of which Mandela would be the most obvious choice, I decided to choose names out of my own immediate history and out of my own cultural and church group. Two names came to my mind: Beyers Naudé and Ben Marais.

\section{THE CHOOSING OF EXAMPLES}

\section{Beyers Naudé}

When I was a boy in grade 12, in 1963, my father was a delegate elder to a synod meeting in Pretoria, which was held in the old synod hall, called the Voortrekker Gedenksaal (notice the resemblance with the name Voortrekker Monument). It was school holidays, and on one afternoon I went with my father to the meeting and sat in the public gallery. I listened to a debate in which Beyers Naudé, the moderator of the synod, was accused of all kinds of negative things because of his involvement with the new monthly journal, Pro Veritate, launched by him. He and a group of supporters to try and lead the church away from apartheid used this journal (Roy 2000:151). It was a heated debate and one of Naudé's main attackers was a minister, Dawie Beukes, who was a high-ranking Afrikaner Broederbond member. At the end of the debate a voting through the raising of hands was held, and a motion was accepted by the synod, which condemned Pro Veritate. I remember my father voting against the motion and from the gallery I saw the uneasy situation in which my father was, voting against the minister delegate sitting next to him. I still remember how proud I was of my father taking his own stand, even against his pastor sitting next to him.

In later years during my university years and in the early years of my ministry, I became involved in the ideological thinking, which formed the basis of the apartheid policy. For many years I was convinced that the policy of "Separate Development", as it was called, could be defended theologically. In this process Beyers Naudé became a name that symbolized anti-patriotism and the enemy of the Afrikaner. During that time I personally chose to forget the afternoon in the synod hall and how impressed I was by both Naudé's contribution to the debate and by my father's decision to vote in his favour. I was taken 
away by the stream of popular thinking in the ranks of my church and cultural group. Today I regret it.

History has proven that Beyers Naudé was a man who was ahead of his time. He saw the unethical elements in the foundations of the apartheid ideology, when nationalism and fear for a black majority blinded many of us. He was willing to take the risk of going against the group to defend a minority point of view. In the process of re-authoring my own story, I would like to honour him and choose him as one of the examples for my life.

\section{Ben Marais}

Ben Marais was my professor in Church History. When I came to the Theological Faculty at the University of Pretoria in the sixties, he was already regarded with suspicion by a large part of the Dutch Reformed Church, because of his political and theological point of view. It is interesting that Beyers Naude was at an early stage influenced by the senior minister, Ben Marais. Marais, of the congregation where they both ministered. Marais wrote a book, Die Kleur Krisis in die Weste (Colour, the Unsolved Problem of the West), and that book disturbed Naude and challenged him to re-examine his understanding of race and human dignity (Roy 2000:150).

Ben Marais managed to remain true to his convictions, and at the same time be accepted as an honored member of the church. He was controversial, but loved. As a student I was impressed by his humanness, friendliness and by his great intellect. In the Faculty he was alone. The shots were called by the apartheid-theologians. He didn't agree with their interpretation of the Bible, through which they theologically justified apartheid. But his point of view was not popular in a time of Afrikaner-nationalism and patriotism.

I cannot choose my history, but I can choose the examples from that history. These two men, Beyers Naudé and Ben Marais are persons I would like to choose as some of my examples. With them in mind, I would like to reshape my future as minister and theologian. I believe they also provide examples for many South Africans in the re-authoring of our stories. 


\section{DREAMING A FUTURE}

I dream of more human dignity for South Africa, and I would like to use a metaphor in order to give content to this dream. I found a metaphor in the wonderful book by James McBride, The Color of Water. A Black Man's Tribute to His White Mother (1998). The following is a part of the conversation between the black son and his white mother:

Does he (God) like black or white people better?

He loves all people. He's a spirit.

What's a spirit?

A spirit's a spirit.

What color is God's spirit?

It doesn't have a color, she said.

God is the color of water. Water doesn't have a color.

To my mind, the challenge to find more human dignity in the South African society will only be accomplished when we can more truly worship the God who is spirit, a God with the color of water. When we truly worship this God, we will not be satisfied with a situation where people are still judged according to the colour of their skin.

Although we have moved away from the legalized system of apartheid, the attitude of racism is still deeply embedded in society. The task of the church is now even more difficult than it was during the times of apartheid, because there is no longer an evil system to address, but attitudes, the fixed patterns of society that is not ruled by law, but by custom. These are difficult issues to address. The church must regard it as its task to teach people to think in terms of the "color of water".

My conclusion after this short autobiographical journey, is that in order for us to come to healing through reconciliation, we need to...

- Share our stories;

- Accept our guilt in spite of the fact that we were also determined by larger systems of privilege; 
- Re-author our history, not in an effort to alter the shame, but to identify with people who are examples of honour.

\section{Consulted literature}

Allende, I, 1988. Eva Luna. New York: Knopf.

Johnston, A G 2001. Privilege, Power, and Difference. Boston: McGraw Hill.

Krog, A 2003. A Change of Tongue. Rosebank: Random House.

McBride, J 1998. The Color of Water. A Black Man's Tribute to His White Mother. London: Bloomsbury.

New York Times, May 9, 2000, A3.

Roy, K 2000. Zion City RSA. Cape Town: South African Baptist Historical Society Time, March 27, 2000, 41. 